\title{
Pelatihan Tata Kelola Keuangan pada Gabungan Kelompok Tani "Maju Mapan" di Kabupaten Jember
}

\author{
Sumadi Sumadi, Rediyanto Putra, Oryza Ardhiarisca
}

\begin{abstract}
Tulisan ini bertujuan untuk melakukan penjelasan mengenai pelaksanaan dan hasil program pengabdian kepada masyarakat yang dilakukan di gabungan kelompok tani Maju Mapan Jember. Tujuan dari pengabdian ini adalah untuk memberikan edukasi sekaligus pelatihan tata kelola keuangan berdasarkan pada ilmu akuntansi. Harapan dilaksanakannya program pengabdian ini adalah para anggota dari gabungan kelompok tani Maju Mapan dapat melakukan tata kelola keuangan dengan baik dan benar, sehingga dapat meningkatkan akuntabilitas pelaporan keuangan yang ada di gabungan kelompok tani tersebut. Program pengabdian ini dibagi menjadi dua tahap yaitu yang pertama adalah tahap pengenalan dan kedua adalah tahap praktik atau pelatihan. Tahap pengenalan merupakan tahap yang melakukan pengenalan diri kepada gabungan kelompok tani Maju Mapan dan pemberian motivasi terkait pentingnya tata kelola keuangan berbasis akuntansi. Tahap kedua merupakan tahap praktik atau pelatihan yang melakukan pelaksanaan pelatihan secara nyata terkait praktik akuntansi yang akan digunakan untuk mengelola keuangan dari gabungan kelompok tani Maju Mapan. Pelaksanaan pengabdian ini diikuti oleh 30 orang peserta yang terdiri dari perwakilan dari masing-masing Unit Pengelohan Hasil (UPH) dan ketua dari gabungan kelompok tani Maju Mapan. Pelaksanaan pengabdian ini menghasilkan pemhaman baru bagi gabungan kelompok tani Maju Mapan terkait pentingnya praktik akuntansi untuk tata kelola keuangan. Selain itu, program pengabdian ini juga menghasilkan buku pencatatan keuangan sederhana yang dapat digunakan oleh anggota gabungan kelompok tani sebagai media untuk melakukan praktik akuntansi dalam kegiatan sehari-hari.
\end{abstract}

\section{Keywords - Akuntabilitas, Akuntansi, Gabungan Kelompok Tani, Tata Kelola Keuangan}

\section{Pendahuluan}

Gabungan Kelompok Tani (Gapoktan) Kopi "Maju Mapan" merupakan gabungan dari kelompok petani kopi yang ada di Kabupaten Jember Jawa Timur. Gapoktan ini didirikan sejak tahun 2012 yang terdiri dari beberapa kelompok tani kopi yang berda di sekitar Kecamatan Panti dan Sukorambi yang berada disekitar lereng Gunung Argopuro. Petani yang menjadi anggota dari gapoktan Maju Mapan saat ini mengelola lahan milik Perhutani. Luas lahan yang dikelola oleh gapoktan Maju Mapan di Kecamatan Panti dan Sukorambi adalah 389,09 hektar dan 107,82 hektar (Dishutbun Kab. Jember, 2015).

Gapoktan Maju Mapan saat ini dipimpin oleh Bapak Mulyadi dan berada dalam bimbingan Dinas Pertanian, Dinas Perkebunan, dan Dinas Kehutanan Jember. Bapak Mulyadi selaku pimpinan/ketua gapoktan Maju Mapan dalam melakukan tugas dan tanggungjawabnya dibantu oleh sekretaris dan bendara yaitu. Gapoktan maju mapan sendiri juga memiliki lima unit usaha yang terdiri dari unit usaha tani, unit usaha pengelolaan, unit usaha dan pelaksanaan, unit pemasaran, dan unit keuangan mikro.

Gapoktan Maju Mapan memiliki beberapa kegiatan terkait produksi kopi yang rutin dilakukan setiap hari. Tabel 1 berikut menyajikan beberapa jenis kegiatan terkait produksi kopi yang dilakukan oleh gapoktan Maju Mapan. 
TABEL 1. KEgIATAN GAPOKTAN MAJU MAPAN

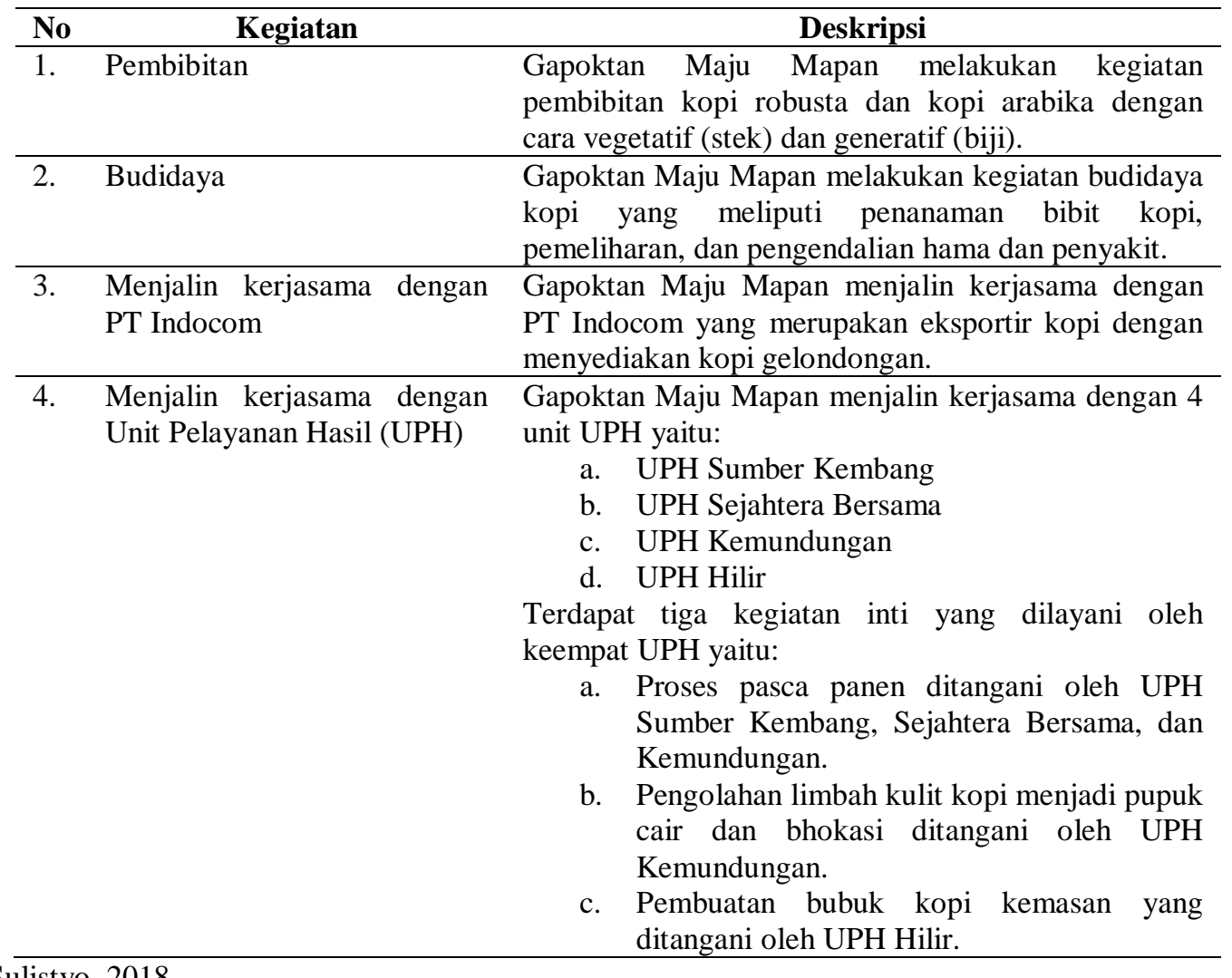

Sumber: Sulistyo, 2018 
Tabel 1 diatas menunjukkan empat jenis kegiatan yang dilakukan oleh gapoktan Maju Mapan terkait produksi kopi. Proses produksi kopi yang dilakukan dimulai dari proses pembibitan hingga pembuatan bubuk kopi melalui penjalinan kerjasama dengan beberapa Unit Pelayanan Hasil (UPH). Hal ini menunjukkan bahwa proses produksi kopi yang dilakukan oleh gapoktan Maju Mapan saat ini sudah cukup baik karena telah mencakup sektor hulu hingga hilir.

Tabel 1 juga menunjukkan bahwa gapoktan Maju Mapan melakukan proses pengolahan limbah dari kulit kopi yang dapat digunakan sebagai pupuk cair dan bhokasi. Dengan demikian, proses produksi kopi yang dihasilkan oleh gapoktan Maju Mapan tidak akan menghasilkan limbah yang dapat menjadi sampah. Selain itu, gapoktan Maju Mapan juga telah memiliki saluran untuk proses ekspor dari kopi glondongan yang dihasilkan melalui kerjasama dengan PT. Indocom.

Penjelasan pada paragraf sebelumnya menunjukkan bahwa gapoktan Maju Mapan memiliki potensi untuk berkembang yang baik jika dilihat dari segi jenis-jenis kegiatan yang telah dilakukan. Namun, dibalik itu semua gapoktan Maju Mapan sampai saat ini masih memiliki kendala dalam kegiatan operasionalnya. Kendala tersebut adalah terkait proses penyusunan laporan keuangan.

Masalah yang dimiliki oleh gapoktan Maju Mapan adalah terkait penyusunan laporan keuangan dikarenakan gapoktan Maju Mapan saat ini masih melakukan proses pembukuan dengan seadanya dan belum memiliki pedoman yang baku. Hal ini terjadi karena rendahnya tingkat pendidikan yang dimiliki oleh para petani kopi. Prayitno (2015) menyebutkan bahwa petani kopi rakyat rata-rata juga mempunyai tingkat pendidikan yang relatif rendah. Tabel 2 berikut menyajikan data pendidikan dari petani kopi rakyat:

TABel 2. Data PENDIDIKAN PETANi Kopi RaKyat

\begin{tabular}{lll}
\hline No & \multicolumn{1}{c}{ Pendidikan } & Prosentase \\
\hline 1 & $\begin{array}{l}\text { Tidak tamat Sekolah } \\
\text { Dasar (SD) }\end{array}$ & $40 \%$ \\
\hline 2 & Sekolah Dasar (SD) & $26,25 \%$ \\
\hline 3 & $\begin{array}{l}\text { Sekolah Menengah } \\
\text { Pertama (SMP) }\end{array}$ \\
\hline 4 & $\begin{array}{l}\text { Sekolah Menengah } \\
\text { Atas (SMA) }\end{array}$ \\
\hline 5 & Diploma & $2,5 \%$ \\
\hline
\end{tabular}

Tabel 2 diatas memperlihatkan bahwa suatu hal yang wajar jika para petani kopi dalam gapoktan memiliki kesulitan dalam menyusun laporan keuangan secara benar. Keterbatasan dalam pendidikan menjadikan para petani kopi yang menjadi anggota dari gapoktan Maju Mapan tidak memahami cara-cara yang seharusnya dilakukan untuk dapat menghasilkan laporan keuangan yang benar. Oleh karena itu, pemberian pelatihan dan pendampingan terkait penyusunan laporan keuangan pada gapoktan Maju Mapan sangat diperlukan.

Pelatihan penyusunan laporan keuangan pada gapoktan Maju Mapan ditujukan agar gapoktan Maju Mapan mampu menghasilkan laporan keuangan yang semestinya untuk kepentingan pengendalian serta pengawasan. Kemampuan dalam penyusunan laporan kuangan secara benar diperlukan oleh gapoktan Maju Mapan karena laporan keuangan merupakan suatu hal yang mutlak dilakukan oleh seluruh sektor dalam perkembangan bisnis saat ini. PSAK No. 1 (2017) menyebutkan bahwa laporan keuangan dapat memberikan informasi terkait posisi keuangan, kinerja keuangan, dan arus kas dari suatu entitas yang bermanfaat bagi sebagian besar pihak berkepentingan dalam pembuatan keputusan ekonomi.

Pelatihan penyusunan laporan keuangan pada gapoktan Maju Mapan juga diperlukan mengingat pada tahun ini gapoktan Maju Mapan mendapatkan dana kredit dari Bank BPR Jatim dalam jumlah yang besar. Berita harian Memo tanggal 4 Mei 2018 menyebutkan bahwa gapoktan Maju Mapan berhasil mendapatkan kucuran dana kredit dari Bank BPR Jatim sebesar 4,8M untuk investasi, biaya operasional budidaya dan pengelolahan, serta dana talangan untuk penyediaan bahan baku. Kucuran dana ini merupakan kedua dari program hulu hilir agromaritim Gubernur Jawa Timur untuk sektor perkebunan di Kabupaten Jember. Dengan demikian, pelatihan mengenai penyusunan laporan keuangan sangat bermanfaat bagi gapoktan Maju Mapan. Pengetahuan mengenai penyusunan laporan keuangan secara benar akan dapat membuat gapoktan Maju Mapan dapat melakukan pengendalian dan pengawasan terkait penggunaan dana yang telah diterima, sehingga proses pengelolaan dana akan menjadi lebih akuntabel.

Pelatihan penyusunan laporan keuangan pada gapoktan Maju Mapan akan disesuaikan dengan standar akuntansi yang sesuai dengan kriteria jenis entitas yang dimiliki gapoktan Maju Mapan. Hal ini dikarenakan gapoktan Maju Mapan merupakan suatu bentuk entitas yang melakukan suatu bentuk kegiatan produksi kopi, sehingga terdapat aset biologis yang harus diakui, diukur dicatat, dan disajikan secara benar agar lebih terkendali. Selain itu, gapoktan Maju Mapan juga merupakan entitas yang belum berbentuk badan hukum dan tidak memiliki akuntabilitas publik. Oleh karena itu, pelatihan dan pendampingan akuntansi akan didasarkan pada Standar Akuntansi Keuangan Entitas Tanpa Akuntanbilitas Publik (SAK-ETAP) dan Pedoman Teknis Pencatatan Transaksi dan Keuangan Badan Usaha Kecil Badan Usaha Bukan Badan Hukum Sektor Pertanian Bank Indonesia. Berdasarkan identifikasi masalah tersebut, maka rumusan masalah yang ada adalah sebagai berikut:

- Bagaimana cara meningkatkan motivasi dari anggota gapoktan Maju Mapan untuk menggunakan akuntansi yang baik dan benar?

- Bagaimana proses penyusunan laporan keuangan atas transaksi-transaksi yang terjadi pada kegiatan operasional gapoktan Maju Mapan?

\section{A. Solusi Masalah}

Solusi yang akan diberikan adalah pemberian pengetahuan dan praktik terkait akuntansi dan laporan 
keuangan. Akuntansi dan laporan keuangan yang diberikan pada pelatihan di gapoktan Maju Mapan didasarkan pada Standar Akuntansi Keuangan Entitas Tanpa Akuntabilitas Publik (SAK-ETAP) dan Pedoman Teknis Pencatatan Transaksi dan Keuangan Badan Usaha Kecil Badan Usaha Bukan Badan Hukum Sektor Pertanian Bank Indonesia.

Ilmu akuntansi yang diberikan nantinya diharapkan mampu membuat proses penyusunan laporan keuangan gapoktan Maju Mapan menjadi lebih baik dan akuntabel. Warsono (2010) menjelaskan bahwa akuntansi merupakan suatu bentuk proses yang sistematis untuk melakukan pengelolahan terhadap suatu transaksi kedalam bentuk informasi keuangan yang ditujukan bagi para pengguna. Dengan demikian, akuntansi bisa dianggap sebagai suatu bentuk komunikasi antara suatu entitas dengan pihak berkepentingan terkait kegiatan operasional yang telah dilakukan. Informasi yang dihasilkan oleh akuntansi disajikan dalam bentuk laporan keuangan.

Ilmu akuntansi yang telah diajarkan kepada gabungan kelompok tani Maju Mapan juga diharapkan dapat digunakan untuk menghasilkan laporan keuangan. Laporan keuangan yang dihasilkan dari proses akuntansi dapat digunakan oleh pihak internal dan eksternal. Proses pengabdian ini akan mempermudah pembuatan laporan keuangan yang dilakukan oleh gabungan kelompok tani Maju Mapan melalui pembuatan buku pencatatan keuangan sederhana. Buku tersebut disusun untuk memudahkan dalam proses pencatatan transaksi keuangan setiap hari. Dengan demikian, gabungan kelompok tani Maju Mapan dapat memantau proses transaksi keuangan yang terjadi. Buku tersebut juga telah menyiapkan format laporan keuangan sederhana untuk gabungan kelompok tani Maju Mapan. Adapun format laporan keuangan yang tersebut terdiri dari laporan posisi keuangan, laporan laba rugi, laporan perubahan ekuitas.

\section{TARGET DAN LUARAN}

Kegiatan pengabdian kepada masyarakat yang telah dilakukan dapat dikatakan berhasil dengan didasarkan pada beberapa tercapainya target yang diinginkan. Target yang ingin dicapai pada pelaksanaan program pengabdian ini adalah para peserta pelatihan ini mampu memahami konsep dasar proses tata kelola keuangan dan melakukan pencatatan terkait transaksi keuangan. Luaran yang dihasilkan pada pelaksanaan program pengabdian ini adalah dibuatnya buku pencatatan keuangan sederhana yang dapat digunakan oleh gabungan kelompok tani sebagai media proses tata kelola keuangan yang lebih baik.

\section{METODE PELAKSANAAN}

Kegiatan pelatihan tata kelola keuangan ini dilakukan pada gapoktan Maju Mapan yang berada di Kabupaten Jember. Fokus peserta pada pelatihan ini adalah pihak-pihak yang berkepentingan secara langsung dengan laporan keuangan yang dihasilkan dan bidang pemasaran. Pihakpihak tersebut yaitu seperti ketua, sekretaris, bendahara, unit usaha keuangan mikro, para pengurus utama Unit Pelayanan Hasil, pengurus utama wanita tani, dan staf administrasi yang ada di gapoktan Maju Mapan. Pelaksanaan kegiatan pengabdian masyarakat ini dilakukan dengan beberapa metode yaitu ceramah, tutorial, praktik, diskusi, dan asessment. Penjelasan secara lebih mendalam terkait sistematika metode kegiatan pengabdian ini adalah sebagai berikut:

1) Ceramah: Metode ini ditujukan untuk memberikan motivasi dari para peserta pelatihan agar memiliki keinginan untuk melakukan penyusunan laporan keuangan dengan baik dan benar.

2) Tutorial: Metode ini dilakukan dengan memberikan gambaran secara jelas mengenai proses kelola keuangan secara jelas dan lengkap sesuai dengan pedoman yang sesuai. Peserta akan diberikan mengenai pengetahuan terkait penyusunan laporan keuangan.

3) Diskusi: Metode ini merupakan metode tanya jawab terkait hal-hal yang belum dipahami oleh peserta pelatihan.

4) Praktik: Metode ini dilakukan dengan memberikan contoh tata kelola keuangan (akuntansi) pada kondisi sebenarnya yang terjadi di lapangan/ tempat gapoktan Maju Mapan. Metode praktik ini juga diikuti oleh para peserta pelatihan untuk belajar melakukan pencatatan keuangan.

5) Asessment: Metode ini dilakukan dengan tujuan untuk melakukan penilaian terhadap program pengabdian yang telah dilaksanakan. Tujuannya adalah melakukan identifikasi perbaikan dan program lanjutan yang perlu dilakukan pada program pengabdian selanjutnya.

\section{HASIL}

Program pengabdian yang dilakukan terkait pelatihan tata kelola keuangan pada gabungan kelompok tani Maju Mapan ini dilakukan melalui dua tahap. Tahap pertama adalah pelaksanaan program pengenalan selanjutnya tahap kedua adalah pelaksanaan program praktik pelatihan tata kelola keuangan. Pelaksanaan program pengabdian ini diikuti oleh 30 peserta dari Unit Pelayanan Hasil (UPH) dan ketua serta sekretaris dari gabungan kelompok tani Maju Mapan.

Tahap pertama pelaksanaan program pengabdian ini memberikan materi pengenalan sebagai berikut:

1) Pengenalan Profil Pelaksana Pengabdian: Materi yang diberikan terkait pengenalan profil pelaksana pengabdian ini bertujuan untuk memberikan informasi secara singkat terkait identitas dari tim pelaksana. Materi ini dilakukan agar peserta pengabdian dapat lebih mengenali para pelaksana. Selain itu, materi selanjutnya adalah materi penyampain tujuan dilakukannya program pengabdian. Dengan demikian, para peserta porgram dapat memahami maksud dan tujuan dari dilakukannya program pengabdian ini.

2) Pengenalan terkait Ilmu Akuntansi: Materi selanjutnya setelah proses pengenalan profil pelaksana 
pengabdian adalah pemberian materi terkait pengantar ilmu akuntansi. Tujuannya adalah agar para peserta pengabdian lebih mengetahui konsep dasar dari akuntansi. Materi ini terdiri dari pengertian dan prinsip dasar akuntansi, tujuan pelaporan keuangan, kualitas laporan keuangan, standar akuntansi.

Tahap selanjutnya setelah dilakukan pemberian materi pengenalan kepada para peserta program pengabdian adalah tahap pelatihan praktik tata kelola keuangan. Tahap ini akan melakukan kegiatan tutorial dan praktik mengenai cara untuk melakukan pencatatan transaksi keuangan dan pembuatan laporan keuangan sederhana. Media yang digunakan dalam tahapan ini adalah buku pencatatan transaksi keuangan sederhana yang telah sebelumnya dibuat untuk mempermudah para peserta dalam melakukan praktik pencatatan. Adapun praktik tata kelola keuangan yang dilakukan pada proses pelatihan ini mencakup pengisian catatan untuk absensi kerja pegawai, pengisian catatan untuk biaya produksi, pengisian catatan untuk biaya non produksi pengisian catatan untuk aset (aset lancar dan tetap), pengisian catatan untuk transaksi penjualan, pengisian catatan untuk kewajiban dan ekuitas, dan pembuatan laporan keuangan.
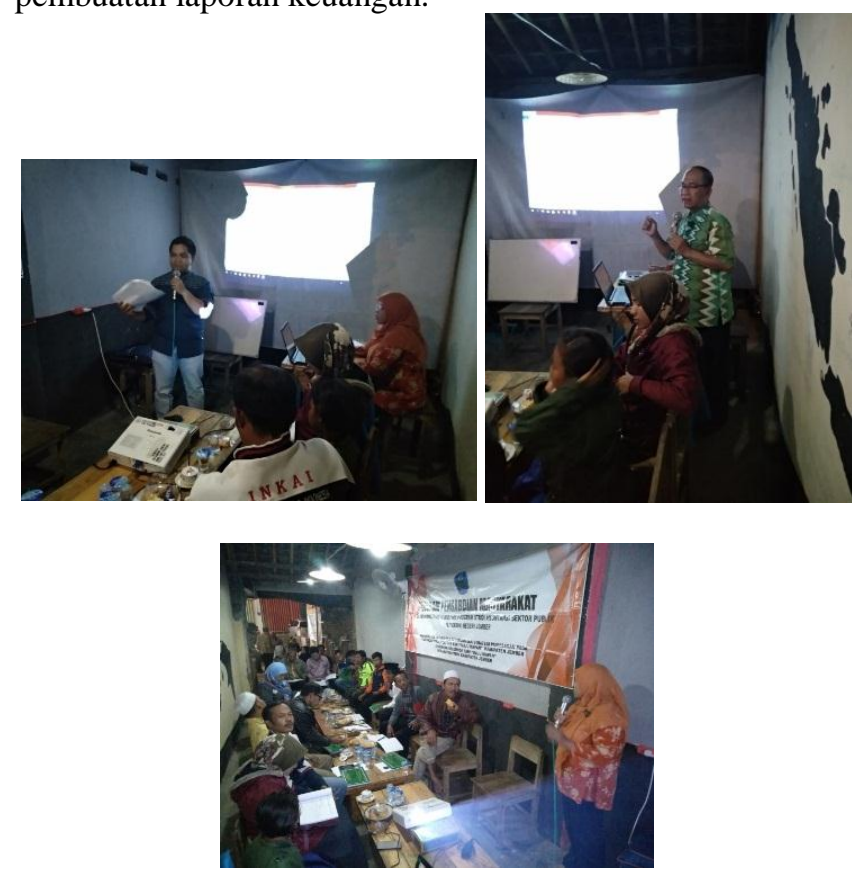

GAMBAR 1. PELAKSANAAN PROGRAM PENGABDIAN
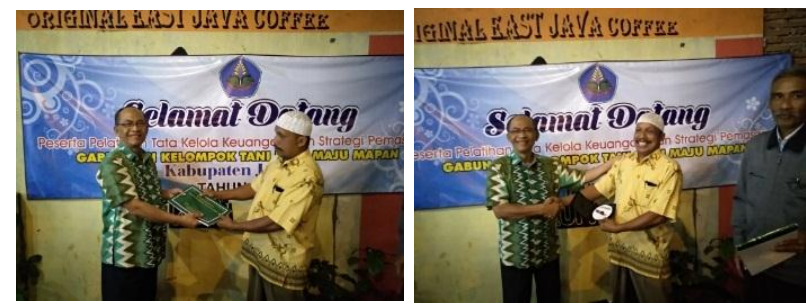

GAmbar 2. PElaksanaAn PEMbERian Buku PENCATATAN KEUANGan SEDERHANA

\section{Kesimpulan Dan SARAN}

Program pengabdian yang telah dilakukan terkait pelatihan tata kelola keuangan pada gabungan kelompok tani Maju Mapan ini telah berhasil dilakukan. Para peserta yang menghadiri program pelatihan ini cukup banyak, hal ini menunjukkan adanya antusias yang tinggi dari para peserta pelatihan. Program pengabdian ini juga telah berhasil memberikan pemahaman terkait penggunaan ilmu akuntansi untuk melakukan tata kelola keuangan pada gabungan kelompok tani Maju Mapan. Selain itu, program pengabdian ini juga telah berhasil menghasilkan buku pencatatan keuangan sederhana yang dapat digunakan oleh gabungan kelompok tani sebagai saran pembuatan laporan keuangan yang lebih baik.

Saran atas pelaksanaan program pengabdian yang telah dilakukan ini adalah perlu adanya keberlanjutan pelaksanaan program di masa yang akan datang. Program pengabdian selanjutnya diharapkan mampu menyiapkan bentuk aplikasi sederhana yang dapat lebih memudahkan proses pelaksanaan tata kelola keuangan pada gabungan kelompok tani Maju Mapan. Pembuatan aplikasi keuangan tersebut dapat didasarkan pada bentuk buku akuntansi yang telah dihasilkan pada program pengabdian saat ini yang telah dievaluasi sesuai dengan kendala atau kekurangan yang dirasakan oleh gabungan kelompok tani Maju Mapan. Dengan demikian, proses tata kelola keuangan di masa yang akan datang dapat lebih mempermudah proses pelaksanaan tata kelola keuangan dan mingkatkan akuntabilitas keuangan di gabungan kelompok tani Maju Mapan.

\section{REFERENSI}

[1] Warsono, S. 2010. Akuntansi ternyata Logis dan Mudah. Yogyakarta: Asgard Chapter

[2] Prayitno. 2016. Pengaruh Lahan, Sumber Daya Manusia dan Teknik Budidaya terhadap Produksi Kopi. Tesis. Jember: Politeknik Negeri Jember.

[3] Sulistyo, P. 2018. Laporan Magang Kerja Pemberdayaan (MKP) "Pembuatan Website sebagai Media Promosi Pengenalan Produk ke Masyarakat di Gapoktan Maju Mapan Kecamatan Panti Kabupaten Jember. Jember: Politeknik Neheri Jember.

[4] Ikatan Akuntan Indonesia (IAI). 2017. Standar Akuntansi Keuangan revisi 2017. Jakarta: Salemba Empat 